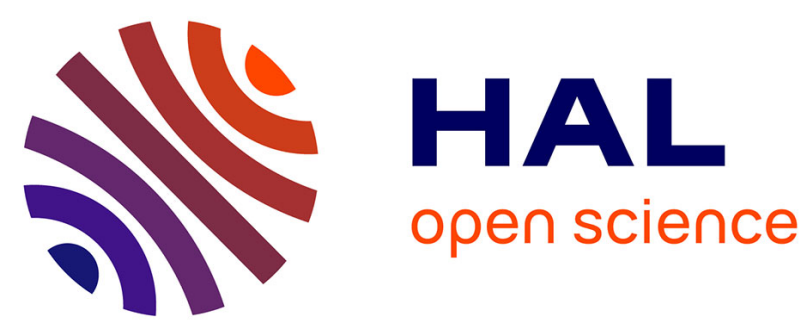

\title{
Effects of ageing under field conditions on soil organic matter in earthworm casts produced by the anecic earthworm Amynthas adexilis in northern Vietnam
} Nicolas Jean Bernard Puche, Cornelia Rumpel, Nicolas Bottinelli

\section{- To cite this version:}

Nicolas Jean Bernard Puche, Cornelia Rumpel, Nicolas Bottinelli. Effects of ageing under field conditions on soil organic matter in earthworm casts produced by the anecic earthworm Amynthas adexilis in northern Vietnam. EGU General Assembly 2021, Apr 2021, online, France. 10.5194/egusphereegu21-14982 . hal-03209160

\section{HAL Id: hal-03209160 \\ https: / hal.sorbonne-universite.fr/hal-03209160}

Submitted on 27 Apr 2021

HAL is a multi-disciplinary open access archive for the deposit and dissemination of scientific research documents, whether they are published or not. The documents may come from teaching and research institutions in France or abroad, or from public or private research centers.
L'archive ouverte pluridisciplinaire HAL, est destinée au dépôt et à la diffusion de documents scientifiques de niveau recherche, publiés ou non, émanant des établissements d'enseignement et de recherche français ou étrangers, des laboratoires publics ou privés. 
EGU21-14982, updated on 27 Apr 2021

https://doi.org/10.5194/egusphere-egu21-14982

EGU General Assembly 2021

(c) Author(s) 2021. This work is distributed under

the Creative Commons Attribution 4.0 License.

\title{
Effects of ageing under field conditions on soil organic matter in earthworm casts produced by the anecic earthworm Amynthas adexilis in northern Vietnam
}

\author{
Nicolas Jean Bernard Puche ${ }^{1}$, Cornelia Rumpel ${ }^{2}$, and Nicolas Bottinelli ${ }^{1,3}$ \\ ${ }^{1}$ IRD, Institute of Ecology and Environmental Sciences (UMR 242 IEES-Paris), Sorbonne Universités, Bondy, France \\ (nicolas.puche@ird.fr) \\ ${ }^{2}$ CNRS, IRD, Institute of Ecology and Environmental Sciences (UMR 242 IEES-Paris) - Paris, UMR (CNRS, IRD, INRA, Sorbonne \\ University, UPEC), Paris, France (cornelia.rumpel@inrae.fr) \\ ${ }^{3}$ Department of Soil Sciences, Soils and Fertilizers Research Institute (SFRI), Hanoi, Viet Nam (nicolas.bottinelli@ird.fr)
}

Carbon sequestration in soils became a major issue that governments have to face under their sustainable development objectives and the international 4p1000 program. Although, earthworms are recognized to play a key role in the structure and dynamics of organic matter (OM) in soils, their contribution to soil OM cycling is not taken into account in biogeochemical models nor well understood. In particular, the fate of OM protected in earthworm casts is unknown. In this study, we investigated the effects of ageing under field conditions on the OM dynamics contained in casts produced by the anecic earthworm Amynthas adexilis in North Vietnam. To this end we investigated (1) the microscale organisation of particulate organic matter and pores during the exposure of casts and control aggregates during 12 months and (2) compared it to the potential OM mineralisation during a laboratory incubation.

Our results indicated that fresh casts contained significantly more particulate organic matter (POM) than control soil aggregates and field aged earthworm casts. Conversely, the porosity was higher in soil control aggregates than in casts and the porosity of casts tended to increase with their ageing. The analyses of micro-CT images also revealed that POM and Pores contents between casts samples presented strong variabilities even in the youngest casts category. We found, on average, higher mineralisation rates for casts than for controls and a reduction of the OM mineralisation with the ageing of casts. Our results also highlighted a strong positive correlation $\left(r^{2}=0.89\right)$ between POM contents determined by the segmentation of micro CT images and $\mathrm{CO}_{2}$ emissions from the incubation experiment. We conclude that earthworms impact the microscale organisation of POM and pores in their casts and thereby influence soil OM dynamics. 